\title{
INHALT DES VIERTEN BANDES
}

\author{
Seite \\ Vorwort . . . . . . . . . . . . . . . . . V V \\ Einleitung .. . . . . . . . . . . . . . . I \\ I. Das Wegsuchen zwischen Nachklassik und Nach- \\ romantik (einschließlich „Biedermeier" und Früh- \\ realismus) . . . . . . . . . . . . . . . . . . 22 \\ Klassizistische Sonderbestrebung: Der Münchener \\ Dichterkreis . . . . . . . . . . . . . . . . II3 \\ II. Die politische Tendenz-Programmatik und Weltan- \\ schauungs-Poetik \\ (Junges Deutschland und Vormärz) . . . . . . . I46
}

III. Die Zielprägung des ideellen und ,poetischen“ Realismus 256

IV. Gattungstheoretische Sonderbeiträge . . . . . . . . 336

Exkurse und Anmerkungen

I. Exkurse zur werkimmanenten Poetik . . . . . . 4 I7

II. Exkurs zur fachwissenschaftlichen Poetik . . . . . . 486

III. Anmerkungen . . . . . . . . . . . . . . . . . 5 I0

Verzeichnis der Begriffe, Merk- und Kennwörter . . . . 699 Verzeichnis der Namen . . . . . . . . . . . . . 740 
